here concerning the other two species referred to,- $S$. maculipennis Scudd. and $S$. aequalis Scudd. From my collections gathered during the last three seasons and notes concerning them taken in the field, I am fully convinced of the distinctness of these species.

S. aequalis I have found one of the most plentiful locusts in New England, everywhere common on dry soil, and very variously colored. With this species I unite $S$. bilineatus Scudd.

$S$. maculipennis on the other hand I have taken only in Southern New England, where I have found it most plentiful near the coast, preferring sandy soils. This species also is very variously colored. Individuals of both species may be wholly either brown or green or any mixture of the two, but green males are the least common of any of the forms and $i_{n}$ some places are exceedingly scarce. Not infrequently specimens show considerable rose-red above or may be very largely blackish-fuscous throughout.

The structural characters presented by the head, vertex, and pronotum are the best means of separating these species from each other and from olivaceus, but the length and markings of the tegmina are also helpful.

It may be of interest in this connection to state that I have examined some of the specimens collected by Prof. S. I. Smith at Norway, Me., and referred to in his paper on the Orthoptera of Maine as $S$. maculipennis, and also some in the collection of Cornell University collected in New York and referred to in Prof. Comstock's Introduction to Entomology under the same name. All of these I am disposed to consider as belonging to aequalis. Some of the Norway, Me., specimens show an unusual length of wing but assuredly are not maculipennis Scudd. I have also examined the types in Mr. Scudder's collection.

\title{
ADDITIONS TO THE LIST OF BOMBYCES AT POUGHKEEPSIE.
}

BY HARRISON G. DYAR, BOSTON, MASS.

In the August, I89I, number of Psyche I gave a list of the Bombyces found in Poughkeepsie, N. Y., and included four species of Arctia. Further study has shown that this list must be increased to seven species. From my series of $A$. virgo I have picked out two specimens which are referable to $A$. intermedia Str. They are of the form in which the markings of the fore wings are practically as in $A$. virgo, being less extensive than in Stretch's figure. This form differs from $A$. parthenice Kirby only in size, and may prove to be a southern race of it. Parthenice occurs not rarely at Plattsburgh, N. Y.; but I have never met with it in Dutchess County. The $\delta$ genitalia of these forms do not differ specifically. I have made drawings from balsam mounts and cannot find any differences which are greater than the range of individual variation. From the same parts in $A$. virgo they differ slightly and probably to a degree which is specific.

Under the term nais in my list were included all the forms with the pattern of marking of that species. I am now satisfied that we have not two species, nais and decorata, as they stand in Professor Smith's list, but three well defined and distinct species, differing in markings of the moth, in the larva according to the observations of Prof. G. H. French and Mr. J. Doll, and in the structure of the $\delta$ genitalia. In another 
paper, in conjunction with Mr. Neumoegen, I give at some length descriptions of these species. Here I will give the synonymy, the accompanying figures of the genitalia and a table of species.

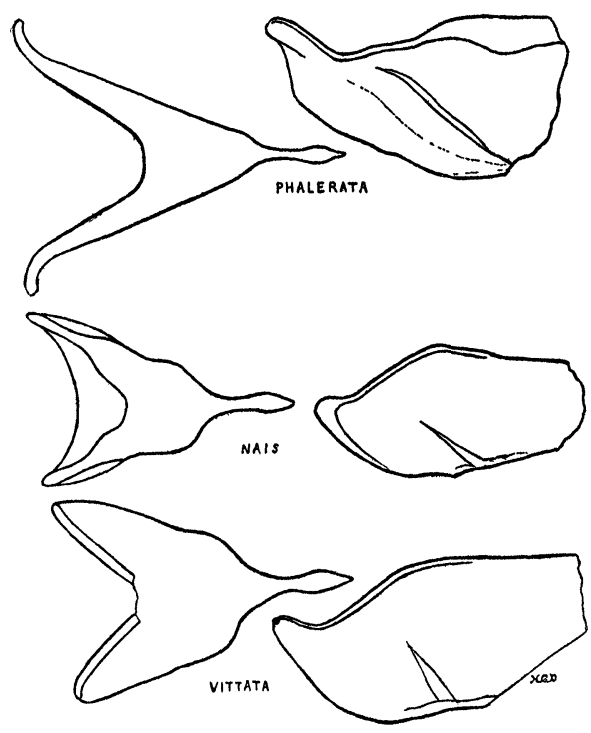

Some of the synonyms given below may be worthy of varietal rank; but I have not access to all the publications and cannot determine the matter.* The references are from Kirby's Catalogue of Lepidoptera Heterocera, Vol. I.

Euprepia (Apantesis) nais Drury. I773-Drury, Ill. ex. ent., i, pl. 7, f. 3 . Noctua.

\section{cuneata Goeze.}

I $78 \mathrm{I}$ - Goeze, Ent. Beytr., iii (3) p. 65, n. ıо. Noctua.

\section{defloriana Martyn.}

* I have not seen defloriana Martyn or vittata Fabr. The form of nais described by Butler as ochreata is worthy of varietal rank if it is different from defloriana; also the two forms of vittata with red and yellow hind wings respectively, when the names can be correctly assorted.
I797-Mart., Psyche, pl.28, ff. 78, 79. Bombyx

ochreata Butler.

I88I - Butl., Ent. mo. mag., xviii, I36. Arctia.

E. (A.) phalerata Harris.

I84I - Harr. Ins. Mass., p. 274. Arctia rhoda Butler.

I88I-Butl., Ent. mo. mag., xviii, I36.

Arctia.

incompleta Butler.

188I - Butl., Ann. mag. nat. hist., (5) viii, 3ri. Arctia.

E. (A.) vittata Fabricius.

I787-Fabr., Mant. ins., ii, p. 127, n. 164 . Bombyx.

radians Walker.

I855-Walk., Cat. Brit. mus., iii, 632. Apantesis.

decorata Saunders.

1853 - Saund., Proc. ent. soc. Phil., ii, 60 Arctia.

colorata Walker.

I864-Walk., Cat. Brit. mus., xxxi, 301 . Aloa.

In tabular form, the specific differences appear thus :-

A. Costal edge of primaries black.

a. Secondaries ocher yellow, rarely tinged with pink; dorsal abdominal black band tapering posteriorly. . . nais.

B. Costal edge of primaries yellow, except at apex.

a. Expanse $34-38 \mathrm{~mm}$; marks of primaries complete or nearly so; abdomen rosy red, the black dorsal band tapering posteriorly; secondaries rosy red along abdominal margin in $\delta$, crimson in $\$$, the spots rarely confluent. . phalerata.

b. Expanse $3^{8-43} \mathrm{~mm}$; marks more or less incomplete, usually markedly so; abdomen ocher yellow, the dorsal black band widened and diffuse posteriorly, often covering most of the surface; secondaries red or ocher yellow with a marginal band of confluent black spots.

vittata. 

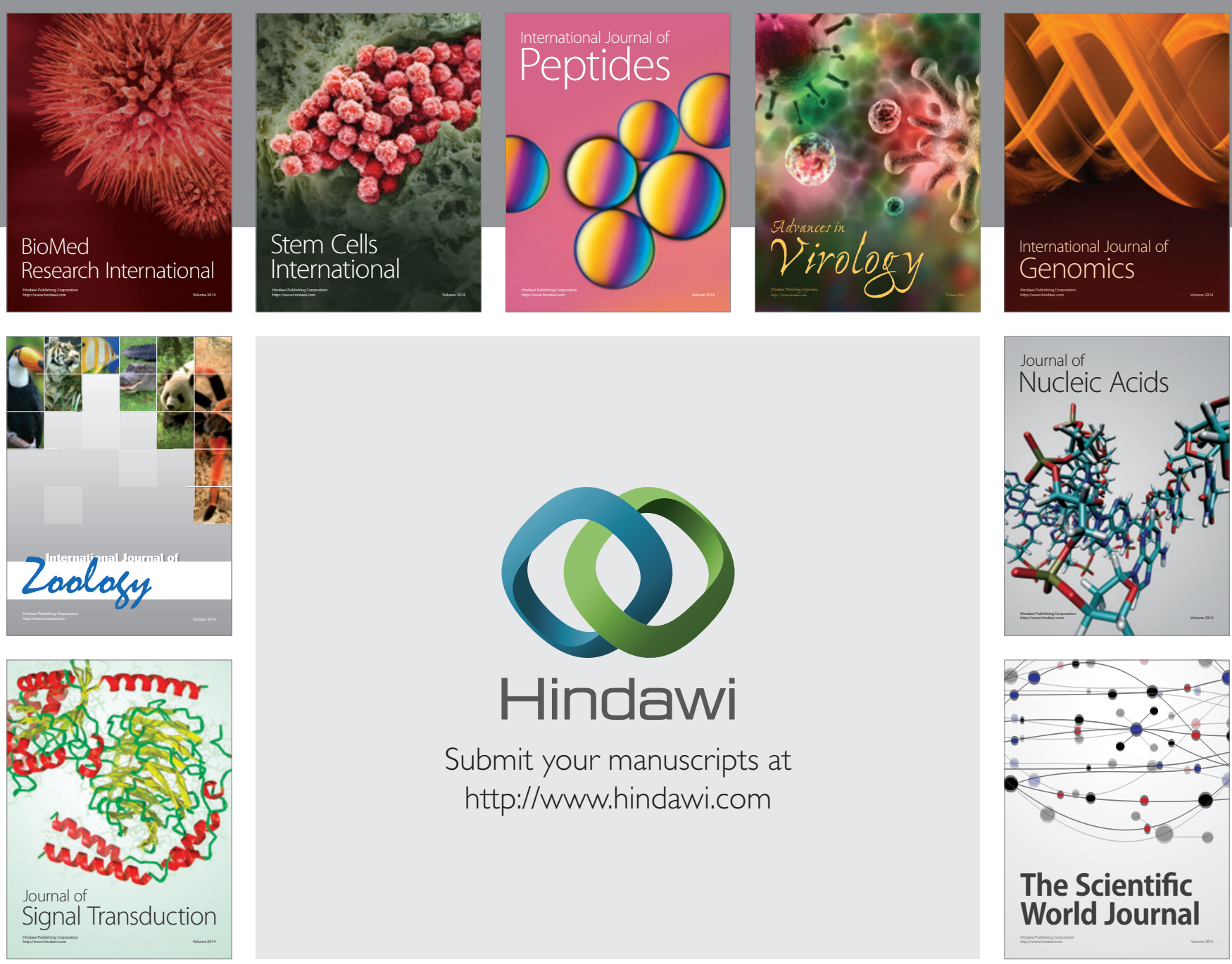

Submit your manuscripts at

http://www.hindawi.com
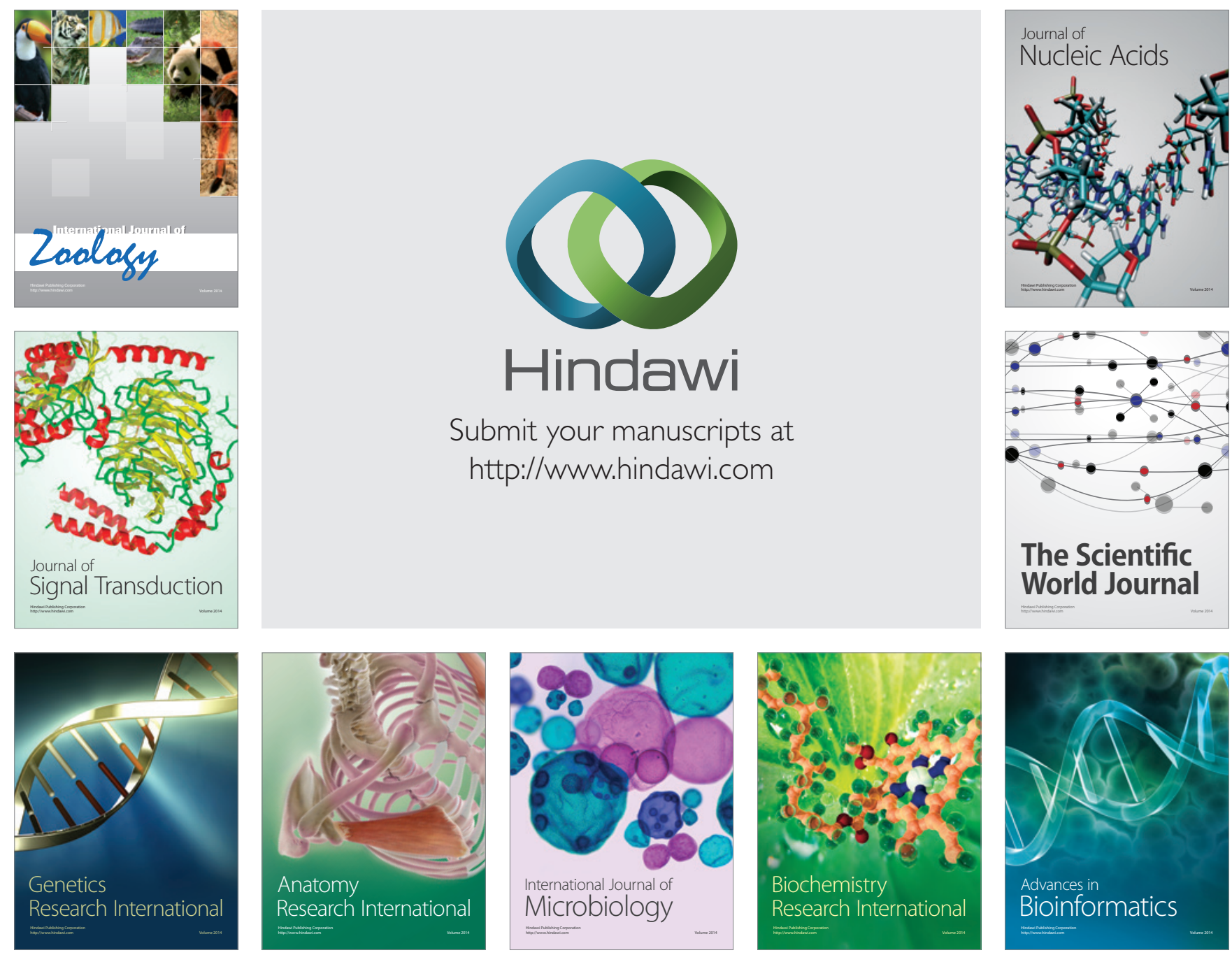

The Scientific World Journal
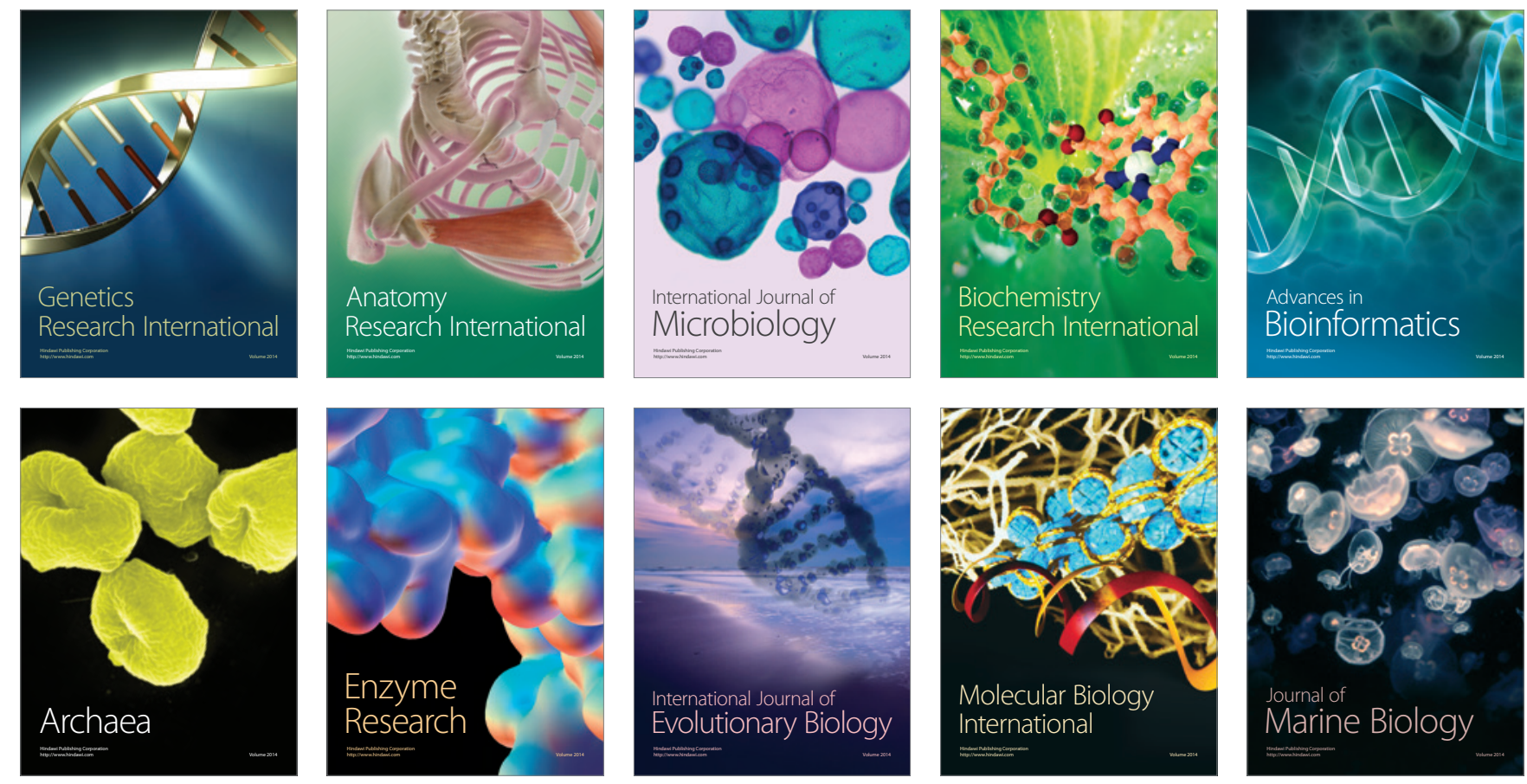